American Journal of Environmental Sciences 6 (1): 66-70, 2010

ISSN 1553-345X

(C) 2010 Science Publications

\title{
Statistical Optimization of Fermentation Conditions for Cellulase Production from Palm Oil Mill Effluent
}

\author{
Jamal I. Daoud and Md. Zahangir Alam \\ Bioenvironmental Engineering Research Unit, Faculty of Engineering, \\ International Islamic University Malaysia, Gombak, 50728 Kuala Lumpur, Malaysia
}

\begin{abstract}
Problem statement: Palm oil mill effluent discharged by the oil palm industries is considered as the mixed of high polluted effluent which is abundant (about 20 million tonnes year ${ }^{-1}$ ) and its effect contributes to the serious environmental problems through the pollution of water bodies. Approach: The aim of this study was to identify the potential of low cost substrate such as Palm Oil Mill Effluent (POME) for the production of cellulase enzyme by liquid state bioconversion. The filamentous fungus Trichoderma harzianum was used for liquid state bioconversion of POME for cellulase production. Statistical optimization was carried out to evaluate the physico-chemical parameters (factors) for maximum cellulase production by 2-level fractional factorial design with six central points. The polynomial regression model was developed using the experimental data including the effects of linear, quadratic and interaction of the factors. The factors involved were substrate (POME) and co-substrate (wheat flour) concentrations, temperature, $\mathrm{pH}$, inoculum and agitation. Results: Statistical analysis showed that the optimum conditions were: Temperature of $30^{\circ} \mathrm{C}$, substrate concentration of $2 \%$, wheat flour concentration of $3 \%, \mathrm{pH}$ of 4 , inoculum of $3 \%$ and agitation of $200 \mathrm{rpm}$. Under these conditions, the model predicted the enzyme production to be about 14 FPU $\mathrm{mL}^{-1}$. Analysis Of Variance (ANOVA) of the design showed a high coefficient of determination $\left(\mathrm{R}^{2}\right)$ value of 0.999 , thus ensuring a high satisfactory adjustment of the quadratic model with the experimental data. Conclusion/Recommendations: This study indicates a better solution for waste management through the utilization of POME for cellulase production that could be used in the industrial applications such as bioethanol production.
\end{abstract}

Key words: Palm oil mill effluent, cellulase enzyme, bioconversion, statistical optimization

\section{INTRODUCTION}

Currently, Malaysia produces 15 million tonnes of crude palm oil per year from which about 12 million tonnes of palm oil is exported, indicates about $52 \%$ of the total world production (Wu et al., 2009). The process to extract oil from the Fresh Fruit Bunch (FFB) requires large amount of water, mainly for sterilizing the fruits and oil clarification, resulting in the discharge of organic, non-toxic wastewater known as Palm Oil Mill Effluent (POME). The quantity of POME produced is about $60 \%$ for every tonne of FBB processed. Thus, about 18-19.5 tonnes effluent (POME) $\mathrm{h}^{-1}$ is generated from the milling process of an average of 30 tonnes FBB $\mathrm{h}^{-1}$ (Rashid et al., 2009).

Several techniques have been developed in order to treat the highly biodegradable POME. Ponding, anaerobic and aeration systems are the most adopted treatment processes practiced by more than $85 \%$ of the palm oil mills in the country (Ma and Ong, 1985). The drawbacks of these systems are the requirement of a large land area and the system suffers from control and maintenance problems, biogas generation caused in air pollution (Ahmad et al., 2003). The production of this effluent always contributes an environmental problem such as the generation of methane during its anaerobic treatment and the production of high COD (Yacob et al., 2005). It is estimated that POME contains $95-96 \%$ water, $0.6-0.7 \%$ oil, $4-5 \%$ total solids, 2-4\% suspended solids, $\mathrm{pH} 4.7$, BOD-25000 $\mathrm{mg} \mathrm{L}^{-1}$, COD-50000 $\mathrm{mg} \mathrm{L}^{-1}$ and total nitrogen-750 $\mathrm{mg} \mathrm{L}^{-1}$ (Rashid et al., 2009). The carbohydrate and other nutrients content in POME effluent enable it to serve as substrate for the production of cellulolytic enzymes by liquid state bioconversion besides its treatment.

Cellulolytic enzyme production has attracted a world-wide attention due to the possibility of using this

Corresponding Author: Md. Zahangir Alam, Bioenvironmental Engineering Research Unit, Faculty of Engineering, International Islamic University Malaysia, Gombak, 50728 Kuala Lumpur, Malaysia 
Am. J. Environ. Sci., 6 (1): 66-70, 2010

enzyme complex for conversion of abundantly available renewable lignocellulosic biomass for production of carbohydrates for numerous industrial applications including bioethanol (Gadjil et al., 1995; Xia and Cen, 1999). Economical production of cellulases is key for feasible bioethanol production from lignocellulosic biomass using cellulase-based processes. To date the production of cellulase has been widely studied in submerged culture processes (liquid state) but the relatively high cost of enzyme production has hindered the industrial applications through various expensive media are used to produce such enzymes (Reczey et al., 1996). The aim of this study was to determine the fermentation conditions by applying the statistical technique utilizing Palm Oil Mill Effluent (POME) as new substrate for the production of cellulase enzyme.

\section{MATERIALS AND METHODS}

Fermentation media: The major substrate/media used in this study was Palm Oil Mill Effluent (POME). The POME of 5-6\% w/w of TSS $(\mathrm{pH} 4.8)$ was collected from oil palm industry named Seri Ulu Langat Palm Oil Mill Sdn. Bhd., Dengkil, Selangor, Malaysia. The POME concentration of $0.5-2 \% \mathrm{w} / \mathrm{w}$ of TSS was prepared by removing the excess water. The final $\mathrm{pH}$ of POME was recorded. The POME was supplemented with co-substrate of $1-3 \%$ w/w of wheat flour as available nutrients for microbe throughout the study (Alam et al., 2003).

Microbial strain and its inoculum preparation: Culture of Trichoderma harzianum was obtained from lab stock, Bioenvironmental Engineering Lab, IIUM. The fungus was maintained on Potato Dextrose Agar (PDA) plates and subcultured once in a month. The fungus was cultured onto the agar, incubated at $32^{\circ} \mathrm{C}$ until the entire plate was covered by fungus. After seven days, $100 \mathrm{~mL}$ sterilized water was poured onto the surface of four agar plates containing the spore culture. The spores on the surface were gently scraped with sterilized glass rod. The spore $\left(3.2 \times 10^{5}\right)$ suspension of Trichoderma harzianum was then filtered into a $250 \mathrm{~mL}$ Erlenmeyer flask and collected for further experiments.

Experimental procedure for cellulase production: The co-substrate of $1-3 \%(\mathrm{w} / \mathrm{v})$ of wheat flour was added into POME with $0.5-2.0 \%(\mathrm{w} / \mathrm{v})$ of TSS. The $\mathrm{pH}$ of the mixture was adjusted to 4-6 by adding $\mathrm{HCl}$ to increase acidity or $\mathrm{NaOH}$ to increase alkalinity. The mixture was sterilized at $121^{\circ} \mathrm{C}$ for $30 \mathrm{~min}$. The inoculum of $1-3 \%$ with $\left(3.2 \times 10^{5}\right)$ spores was added into
Table 1: Levels of experimental factors for optimization

\begin{tabular}{lccc}
\hline Factor & Low $(-1)$ & Center $(0)$ & High $(+1)$ \\
\hline Temperature ${ }^{\circ} \mathrm{C}$ & 30.0 & 32.50 & 35 \\
Substrate conc $(\%)$ & 0.5 & 1.25 & 2 \\
Co-substrate conc $(\%)$ & 1.0 & 2.00 & 3 \\
Agitation, rpm & 100.0 & 175.00 & 250 \\
pH & 4.0 & 5.00 & 6 \\
Inoculums size (\%) & 1.0 & 2.00 & 3 \\
\hline
\end{tabular}

the flask and shaken in the shaker at agitation speed of 100-250 rpm. The $\mathrm{pH}$ and temperature was set at 4-6 and $30-35^{\circ} \mathrm{C}$ respectively during fermentation process. Sampling was done after four days of fermentation for the analysis of cellulase enzymes.

Experimental design and optimization: Fractional factorial design with six center points was performed in order to determine the optimal fermentation conditions for the production of cellulase enzyme by Trichoderma harzianum. The experiments were conducted according to the designated two-level factorial design. In this design, six factors (parameters) with three levels (low, high and medium) were considered for determining the total number of experiments for optimization of cellulase production by liquid state bioconversion. The experiment was design using Minitab $^{\mathrm{TM}}$ statistical software. The factors with their levels are shown in Table 1.

Statistical and analytical analysis: Statistical software, Minitab ${ }^{\mathrm{TM}}$ was used to analyze regression model of experimental data. The value of F-test, p-test, $\mathrm{t}$-test and $\mathrm{R}^{2}$ were identified to evaluate the model as well as to determine the optimum conditions. Cellulase activity assay was carried out by the method suggested by Ghose (1987).

\section{RESULTS}

The statistical optimization approach using fractional factorial design was used to study the linear, quadratic and interactive effects of various parameters on higher cellulase production by Trichoderma harzianum. The observed (experimental) and predicted results for cellulase enzyme production were obtained with different conditions is shown in Table 2. The highest cellulase activity (13.44 FPU $\mathrm{mL}^{-1}$ ) was observe at run number 23 , where the factors were found to be temperature $30^{\circ} \mathrm{C}$, substrate concentration $2 \%$ and co-substrate concentration $3 \%, \mathrm{pH} 4$, inoculum size $3 \%$ and agitation $250 \mathrm{rpm}$. The experimental result was then analyzed by regression analysis, which gave the following regression Eq. 1 of the levels of cellulase produced (FPU $\left.\mathrm{mL}^{-1}\right)$ as a function of temperature $\left(\mathrm{x}_{1}\right)$, 
Am. J. Environ. Sci., 6 (1): 66-70, 2010

Table 2: Result using two level fractional factorial design and six center points showing observed and predicted response (cellulase)

\begin{tabular}{|c|c|c|c|c|c|c|c|c|}
\hline \multirow[b]{2}{*}{ Run } & \multirow{2}{*}{$\begin{array}{l}\text { Temperature } \\
\left({ }^{\circ} \mathrm{C}\right)\end{array}$} & \multirow{2}{*}{$\begin{array}{l}\text { Subs conc. } \\
(\%)\end{array}$} & \multirow{2}{*}{$\begin{array}{l}\text { Co-s conc. } \\
(\%)\end{array}$} & \multirow[b]{2}{*}{$\mathrm{pH}$} & \multirow{2}{*}{$\begin{array}{l}\text { Inoculum } \\
\text { size }(\%)\end{array}$} & \multirow{2}{*}{$\begin{array}{l}\text { Agitation } \\
\text { (rpm) }\end{array}$} & \multicolumn{2}{|c|}{ Cellulase, FPU mL ${ }^{-1}$} \\
\hline & & & & & & & Experimental & Predicted \\
\hline$\overline{1}$ & 30.0 & 0.5 & 1 & 4 & 1 & 100 & 3.277 & 2.673 \\
\hline 2 & 35.0 & 0.5 & 1 & 4 & 1 & 250 & 2.643 & 1.941 \\
\hline 3 & 30.0 & 2.0 & 1 & 4 & 1 & 250 & 2.643 & 2.194 \\
\hline 4 & 35.0 & 2.0 & 1 & 4 & 1 & 100 & 7.400 & 6.848 \\
\hline 5 & 30.0 & 0.5 & 3 & 4 & 1 & 250 & 2.696 & 2.118 \\
\hline 6 & 35.0 & 0.5 & 3 & 4 & 1 & 100 & 2.273 & 1.540 \\
\hline 7 & 30.0 & 2.0 & 3 & 4 & 1 & 100 & 0.000 & -0.490 \\
\hline 8 & 35.0 & 2.0 & 3 & 4 & 1 & 250 & 3.859 & 3.243 \\
\hline 9 & 30.0 & 0.5 & 1 & 6 & 1 & 250 & 0.000 & -0.578 \\
\hline 10 & 35.0 & 0.5 & 1 & 6 & 1 & 100 & 3.753 & 2.984 \\
\hline 11 & 30.0 & 2.0 & 1 & 6 & 1 & 100 & 0.000 & -0.486 \\
\hline 12 & 35.0 & 2.0 & 1 & 6 & 1 & 250 & 1.797 & 1.225 \\
\hline 13 & 30.0 & 0.5 & 3 & 6 & 1 & 100 & 10.360 & 9.678 \\
\hline 14 & 35.0 & 0.5 & 3 & 6 & 1 & 250 & 5.550 & 4.749 \\
\hline 15 & 30.0 & 2.0 & 3 & 6 & 1 & 250 & 12.421 & 11.900 \\
\hline 16 & 35.0 & 2.0 & 3 & 6 & 1 & 100 & 0.000 & -0.676 \\
\hline 17 & 30.0 & 0.5 & 1 & 4 & 3 & 250 & 1.850 & 1.349 \\
\hline 18 & 35.0 & 0.5 & 1 & 4 & 3 & 100 & 5.286 & 4.661 \\
\hline 19 & 30.0 & 2.0 & 1 & 4 & 3 & 100 & 0.000 & -0.362 \\
\hline 20 & 35.0 & 2.0 & 1 & 4 & 3 & 250 & 4.863 & 4.431 \\
\hline 21 & 30.0 & 0.5 & 3 & 4 & 3 & 100 & 6.343 & 5.861 \\
\hline 22 & 35.0 & 0.5 & 3 & 4 & 3 & 250 & 2.326 & 1.750 \\
\hline 23 & 30.0 & 2.0 & 3 & 4 & 3 & 250 & 13.443 & 13.048 \\
\hline 24 & 35.0 & 2.0 & 3 & 4 & 3 & 100 & 0.439 & -0.034 \\
\hline 25 & 30.0 & 0.5 & 1 & 6 & 3 & 100 & 7.559 & 7.063 \\
\hline 26 & 35.0 & 0.5 & 1 & 6 & 3 & 250 & 2.114 & 1.568 \\
\hline 27 & 30.0 & 2.0 & 1 & 6 & 3 & 250 & 3.330 & 2.994 \\
\hline 28 & 35.0 & 2.0 & 1 & 6 & 3 & 100 & 1.216 & 0.774 \\
\hline 29 & 30.0 & 0.5 & 3 & 6 & 3 & 250 & 2.167 & 1.673 \\
\hline 30 & 35.0 & 0.5 & 3 & 6 & 3 & 100 & 5.920 & 5.263 \\
\hline 31 & 30.0 & 2.0 & 3 & 6 & 3 & 100 & 0.000 & -0.374 \\
\hline 32 & 35.0 & 2.0 & 3 & 6 & 3 & 250 & 6.449 & 5.993 \\
\hline 33 & 32.5 & 1.5 & 2 & 5 & 2 & 175 & 1.586 & 0.836 \\
\hline 34 & 32.5 & 1.5 & 2 & 5 & 2 & 175 & 1.691 & 0.836 \\
\hline 35 & 32.5 & 1.5 & 2 & 5 & 2 & 175 & 1.427 & 0.836 \\
\hline 36 & 32.5 & 1.5 & 2 & 5 & 2 & 175 & 1.269 & 0.836 \\
\hline 37 & 32.5 & 1.5 & 2 & 5 & 2 & 175 & 1.004 & 0.836 \\
\hline 38 & 32.5 & 1.5 & 2 & 5 & 2 & 175 & 1.163 & 0.836 \\
\hline
\end{tabular}

Table 3: ANOVA for polynomial model derived from experimental

\begin{tabular}{lrrrll}
\hline Source & DF & \multicolumn{1}{c}{ SS } & \multicolumn{1}{c}{ MS } & F & P \\
\hline Regression & 31 & 419.100 & 13.519 & 237.40 & 0.000 \\
Residual error & 6 & 0.324 & 0.057 & & \\
Total & 37 & 419.442 & & &
\end{tabular}

$\mathrm{R}^{2}: 0.999 ; \mathrm{R}^{2}$-adj: 0.995

SS: Sum of Squares; DF: Degree of Freedom; MS: Mean Square

substrate concentration $\left(\mathrm{x}_{2}\right)$, co-substrate concentration $\left(\mathrm{x}_{3}\right)$, inoculums size $\left(\mathrm{x}_{4}\right), \mathrm{pH}\left(\mathrm{x}_{5}\right)$ and agitation $\left(\mathrm{x}_{6}\right)$ :

$$
\begin{aligned}
& \text { Cellulase }=155-17.0 \mathrm{x}_{1}-89.4 \mathrm{x}_{2}+50.4 \mathrm{x}_{3}+59.2 \mathrm{x}_{4}+ \\
& \left(\text { FPU mL }{ }^{-1}\right) \quad 77.2 \mathrm{x}_{5}+0.0841 \mathrm{x}_{6}+0.382 \mathrm{x}_{1}^{2}+2.66 \mathrm{x}_{1} \mathrm{x}_{2} \text { - } \\
& 1.69 \mathrm{x}_{1} \mathrm{x}_{3}-1.79 \mathrm{x}_{1} \mathrm{x}_{4}-2.30 \mathrm{x}_{1} \mathrm{x}_{5^{-}} \\
& 0.00450 \mathrm{x}_{1} \mathrm{x}_{6}+9.82 \mathrm{x}_{2} \mathrm{x}_{3}+2.31 \mathrm{x}_{2} \mathrm{x}_{4}+ \\
& 0.830 \mathrm{x}_{2} \mathrm{x}_{5}+0.326 \mathrm{x}_{2} \mathrm{x}_{6}-7.91 \mathrm{x}_{3} \mathrm{x}_{4}- \\
& 6.61 \mathrm{x}_{3} \mathrm{x}_{5}+0.0204 \mathrm{x}_{3} \mathrm{x}_{6}-12.9 \mathrm{x}_{4} \mathrm{x}_{5}- \\
& 0.0979 \mathrm{x}_{4} \mathrm{x}_{6}+0.00218 \mathrm{x}_{5} \mathrm{x}_{6}
\end{aligned}
$$

The ANOVA from the analysis are shown in Table 3. The results showed that the coefficient of determination $\left(\mathrm{R}^{2}\right)$ was 0.999 and $\mathrm{R}^{2}$-adj was 0.995 which ensured satisfactory adjustment of the quadratic model to the experimental data. The value of adjusted determination coefficient is also very high indicating a high significance of the model. The F-value is a measure of variation of the data about the mean. The high $\mathrm{F}$-value and very low probability $(\mathrm{p}>\mathrm{F}=0.0000)$ indicates that the present model is in good prediction of the experimental result. The t-and $\mathrm{p}$-values for the single, quadratic and interactive effects on the response are shown in Table 4 to evaluate the significance levels $(\mathrm{p}<0.01$ or $\mathrm{p}<0.5)$.

\section{DISCUSSION}

The $t$-value and probability value ( $p$-value) serves as a tool for checking the significant of each of the coefficient. 
Am. J. Environ. Sci., 6 (1): 66-70, 2010

Table 4: t-value and p-value for each coefficient of the parameters and their interactions

\begin{tabular}{lrrl}
\hline Predictor & Coefficient & \multicolumn{1}{c}{$\mathrm{t}$} & $\mathrm{P}$ \\
\hline Constant & 15535.0000 & 7.07 & 0.000 \\
Temp, $\mathrm{x}_{1}$ & -17.0000 & -14.43 & 0.000 \\
Subs conc, $\mathrm{x}_{2}$ & -89.4100 & -19.41 & 0.000 \\
Co-s conc, $\mathrm{x}_{3}$ & 50.3520 & 14.81 & 0.000 \\
$\mathrm{pH}, \mathrm{x}_{4}$ & 59.1670 & 25.92 & 0.000 \\
Inoculum, $\mathrm{x}_{5}$ & 77.2390 & 24.52 & 0.000 \\
Agitation, $\mathrm{x}_{5}$ & 0.0841 & 2.00 & 0.092 \\
$\mathrm{x}_{1}{ }^{2}$ & 0.3825 & 22.32 & 0.000 \\
$\mathrm{x}_{1} \mathrm{X}_{2}$ & 2.6573 & 18.81 & 0.000 \\
$\mathrm{x}_{1} \mathrm{X}_{3}$ & -1.6900 & -16.20 & 0.000 \\
$\mathrm{x}_{1} \mathrm{X}_{4}$ & -1.7880 & -25.53 & 0.000 \\
$\mathrm{x}_{1} \mathrm{X}_{5}$ & -2.3010 & -23.82 & 0.000 \\
$\mathrm{x}_{1} \mathrm{X}_{6}$ & -0.0045 & -3.49 & 0.013 \\
$\mathrm{X}_{2} \mathrm{X}_{3}$ & 9.8247 & 13.40 & 0.000 \\
$\mathrm{x}_{2} \mathrm{X}_{4}$ & 2.3059 & 3.14 & 0.020 \\
$\mathrm{x}_{2} \mathrm{X}_{5}$ & 0.8301 & 1.13 & 0.301 \\
$\mathrm{x}_{2} \mathrm{X}_{6}$ & 0.3262 & 33.36 & 0.000 \\
$\mathrm{x}_{3} \mathrm{X}_{4}$ & -7.9104 & -14.38 & 0.000 \\
$\mathrm{x}_{3} \mathrm{X}_{5}$ & -6.6121 & -12.02 & 0.000 \\
$\mathrm{x}_{3} \mathrm{X}_{6}$ & 0.0204 & 2.79 & 0.032 \\
$\mathrm{x}_{4} \mathrm{X}_{5}$ & -12.8990 & -23.45 & 0.000 \\
$\mathrm{x}_{4} \mathrm{X}_{6}$ & 0.0979 & -13.35 & 0.000 \\
$\mathrm{x}_{5} \mathrm{X}_{6}$ & 0.0022 & 3.88 & 0.008 \\
\hline
\end{tabular}

The pattern of interactions between the variables is indicated by these coefficients. The larger the magnitude of t-test value and smaller the p-value indicates the high significance of the corresponding coefficient. The variable with low probability levels contribute to the model, whereas the other can be neglected and eliminated from the model. The p-value suggest that the coefficient for linear effect of temperature, $\mathrm{x}_{1}$, substrate concentration, $\mathrm{x}_{2}$, cosubstrate concentration, $\mathrm{x}_{3}$, inoculums size, $\mathrm{x}_{4}$ and $\mathrm{pH}$, $\mathrm{x}_{5}$, are most significant with value of $\mathrm{p}<0.000$ (Table 4). The p-value of the coefficient of interactive effect of substrate concentration and agitation $\left(\mathrm{x}_{2} \mathrm{x}_{6}\right)$ had value of 0.0000 , which is highly significant. Thus, from this result, it was clear that through the linear effect of agitation was not highly significant for cellulase production from Trichoderma harzianum, its addition to the design could not be totally overruled because of its interactive effect with wheat flour.

\section{CONCLUSION}

The results show that the optimum conditions for maximum cellulase production (about $14 \mathrm{FPU} \mathrm{mL}^{-1}$ ) using palm oil mills effluent by liquid state bioconversion was found to be the temperature, $30^{\circ} \mathrm{C}$; substrate concentration, $2 \% \quad(\mathrm{w} / \mathrm{v}) ;$ co-substrate concentration, $3 \%(\mathrm{w} / \mathrm{v}) ; \mathrm{pH}, 4$; inoculum size, $3 \%$ $(\mathrm{w} / \mathrm{v})$ and agitation, $250 \mathrm{rpm}$. The optimization study of fermentation conditions using two-level fractional factorial design would enhance the production of enzymes at different levels using POME as substrate. The lab-scale study on cellulase production from POME as major substrate might give the basic information of further development for large scale production.

\section{ACKNOWLEDGMENT}

The researchers thank to the Ministry Of Higher Education (MOHE) for approval a research grant under Fundamental Research Grant Scheme (FRGS 0207-49). The co-operation of Seri Ulu Langat Palm Oil Mill Sdn. Bhd., Dengkil, Selangor, by supplying the experimental samples is acknowledged as well.

\section{REFERENCES}

Ahmad, A.L., S. Ismail and S. Bhatia, 2003. Water recycling from Palm Oil Mill Effluent (POME) using membrane technology. Desalination, 157: 87-95. DOI: 10.1016/S0011-9164(03)00387-4

Alam, M.Z., A. Fakhru'l-Razi and A.H. Molla, 2003. Biosolids accumulation and biodegradation of domestic wastewater treatment plant sludge by developed liquid state bioconversion process using a batch fermenter. Water Res., 37: 3569-3578. DOI: 10.1016/S0043-1354(03)00260-4

Gadjil, N.J., H.F. Oaginawala, T. Chakarbartu and P. Khanna, 1995. Enhanced cellulase production by a mutant of Trichoderma reseei. Enz. Microb. Technol., 17: 942-946. DOI: 10.1016/01410229(94)00131-A

Ghose, T.K., 1987. Measurement of cellulase activities. Pure Applied Chem., 59: 257-268. DOI: 10.1351/pac198759020257

Ma, A.N. and A.S.H. Ong, 1985. Pollution control in palm oil mills in Malaysia. J. Am. Oil Chem. Soc., 62: 261-266. DOI: 10.1007/BF02541389

Rashid, S.S., M.Z. Alam, M.I.A. Karim and H.M. Salleh, 2009. Management of palm oil mill effluent through production of cellulases by filamentous fungi. World J. Microbiol. Biotechnol., 25: 2219-2226. DOI: $10.1007 / \mathrm{s} 11274-009-0129-9$

Reczey, K., Z.S. Szengyel, R. Eklund and G. Zacchi, 1996. Cellulase production by T. reesei. Bioresour. Technol., 57: 25-30. DOI: 10.1016/09608524(96)00038-7 
Wu, T.W., A.W. Mohammad, J.M. Jahim and N. Anuar, 2009. A holistic approach to managing palm Oil Mill Effluent (POME): Biotechnological advances in the sustainable reuse of POME, Biotechnol. Adv., 27: 40-52. DOI: 10.1016/j.biotechadv.2008.08.005

Xia, L. and P. Cen, 1999. Cellulase production by solid state fermentation on lignocellulosic waste from the xylose industry. Process Biochem., 34: 909-912. DOI: 10.1016/S0032-9592(99)00015-1
Yacob, S., M.A. Hassan, Y. Shirai, M. Wakisaka and S. Subash, 2005. Baseline study of methane emission from open digesting tanks of palm oil mill effluent treatment. Chemosphere, 59: 1575-1581. DOI: $10.1016 /$ j.chemosphere.2004.11.040 